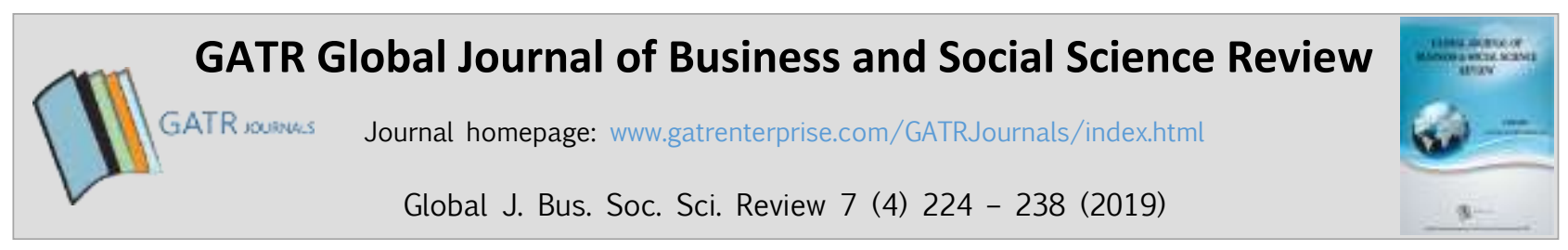

\title{
Enhancing the Performance of Village-Owned Enterprises: The Role of Transformational Leadership and Organizational Capabilities
}

\author{
Ria Nelly Sari*, Dewi Junita, Rita Anugerah, Raisya Zenita \\ Department of Accounting, Faculty of Economics and Business, Universitas Riau, Kampus Bina Widya, Km. 12.5 \\ Simpang Baru, Panam, 28293, Pekanbaru, Indonesia
}

\begin{abstract}
Objective - This study aims to investigate the extent to which transformational leadership could enhance financial and social performance of village-owned enterprises through organizational capabilities.

Methodology/Technique - This study conducted a survey involving village-owned enterprises in Siak Regency, Indonesia. 121 questionnaires were distributed directly to the directors of village-owned enterprises and 89 completed and usable responses were received. Data was analyzed using WarpPLS 5.0 to determine that transformational leadership, directly and indirectly through organizational capabilities can enhance financial and social performance of village-owned enterprises.

Finding - This study demonstrates that transformational leadership has a positive direct effect on organizational performance. Transformational leadership also has a positive effect on organizational performance through organizational capabilities. This study proves that organizational capabilities act as a partial mediator on the relationship between transformational leadership and organizational performance. Novelty - The results of this study demonstrate that transformational leaders are important in improving the performance of village owned enterprises. Therefore, this study suggests that village consultative bodies need to consider the behavioural characteristics of transformational leadership in recruiting village-owned enterprise directors.
\end{abstract}

Type of Paper: Empirical.

Keywords: Transformational Leadership; Organizational Capabilities; Financial Performance; Social Performance; Village-owned Enterprises.

Reference to this paper should be made as follows: Sari, R.N; Junita, D; Anugerah, R; Zenita, R. (2019). Enhancing the Performance of Village-Owned Enterprises: The Role of Transformational Leadership and Organizational Capabilities, Global J. Bus. Soc. Sci. Review 7(4): 224 - 238. https://doi.org/10.35609/gjbssr.2019.7.4(3)

JEL Classification: L21, L25.

\section{Introduction}

As a business entity owned by the village, Village-Owned Enterprise has a very important role for all elements in the village in Indonesia.

\footnotetext{
* Paper Info: Revised: September 15, 2019

Accepted: December 31, 2019

* Corresponding author: Ria Nelly Sari

E-mail: ria.nellysari@lecturer.unri.ac.id

Affiliation: Faculty of Economics and Business, Universitas Riau, Indonesia.
} 
Village-Owned Enterprise is expected to improve the economy of the community and the village, by doing business that suits the potential of the village. Therefore, to achieve its mission, this organization has to demonstrate financial success and welfare for the village community.

The success of an organization cannot be separated from the ability of organizational leaders to optimize the resources of the organization. One of the abilities that organizational leaders need to have is the ability to make changes, which is known as transformational leadership. Transformational leadership is a type of leadership where the leader has the ability to motivate employees to do their work beyond the minimum limit of their job description. Transformational leadership theory shows that transformational leadership is not only related to individual employee performance but also performance at the group and organizational level (Bass, 1985; Chen et. al., 2019).

Leaders who have the ability to influence subordinates in certain ways to make a change can enable the organization to exist in a dynamic environment. For organizations to continue to survive in a dynamic environment, organizations must develop capabilities to enhance core business processes and sustainable learning (Zoot, 2003). The capability referred to here is the ability of the organization to carry out its tasks or activities in a coordinated manner so as to achieve organizational goals (O'Regan et. al., 2006). Thus, the organization will be able to improve its performance. Several studies have found that the capabilities of a company have a positive impact on organizational performance (Henri, 2006; Krasnikov \& Jayachandran, 2008; Lekatompessy, 2012; López-Cabarcos, et. al., 2019; López-Cabarcos, et. al., 2015; Spanos \& Lioukas, 2001).

Village-owned enterprises are expected to improve the economy of the community and the village. They are able to choose a type of business that is suited to the potential of the village. These types of businesses include: social businesses, rentals, broking, production, trade and financial services. Of the various types of businesses, most Village-Owned Enterprise chose to operate in the savings and loan businesses. With the condition of savings and loan businesses that have little income and high risk, many Village-Owned Enterprise experience non-performing loans (krjogja.com). In addition, Village-Owned Enterprises engaged in small and medium scale financial services have certain competitors, namely the Rural Bank (in Indonesian term is BPR) and Cooperatives. With a high level of competition and change, Village-Owned Enterprises must have the capability to be able to show good performance and be able to compete with dynamic competition.

This study aims to investigate the effect of transformational leadership on organizational capabilities and its effect on the financial and social performance of village-owned enterprises. Village-owned enterprises have an important role in improving village welfare, therefore village-owned enterprises must be able to achieve the financial and social goals of the village-owned enterprise itself. Like any other enterprises, the leaders of village-owned enterprises have an important role in planning and utilizing the organization's resources and achieving organizational goals.

Based on the discussion above, this study aims to investigate to what extent leaders that are categorized as transformational leaders are able to enhance the capabilities of an organization, particular of a village-owned enterprise facing a dynamic environment, and therefore will have an impact in leveraging the performance of the organization itself. Past studies on transformational leadership have focused on profit organizations (Chen et. al., 2019; Hamidizadeh, Oboudi \& Ramezani, 2017; Lekatompessy, 2012; López-Cabarcos, et. al., 2019; López-Cabarcos, et. al., 2015; Song et. al., 2007). Therefore, this study contributes to the existing literature by providing evidence of the importance of the role of transformational leadership and organizational capabilities to enhance the financial and social performance of village-owned enterprises. Therefore, this study suggests that village consultative bodies need to consider the characteristics of directors who have a transformational leadership style in recruiting village-owned enterprise directors.

The rest of this paper is organised as follows. Section 2 presents the literature review and hypothesis development. A discussion of the research methodology is provided in Section. 3. Section 4 reports the results and explanation of the study. Finally, section 5 present concludes the study. 


\section{Literature Review and Hypotheses Development}

We developed a conceptual framework for this study based on previous literature relating to leadership, organizational capability, organizational performance, resource-based view theory (RBV) and dynamic capability theory. The RBV believes that competitive advantage and performance of organizations depends on how organizations utilize their available resources, which are scarce and difficult to emulate by competitors in the market (Barney, 1991). Organizations will achieve superior performance and a sustainable competitive advantage if competitors find it difficult to imitate company resources with other alternatives and require high costs to replicate them (Amit \& Schoemaker, 1993).

The rapidly changing environment is encouraging companies to pay more attention to dynamic capability. Dynamic capability is the development of RBV theory. Dynamic capability is defined as the ability to perceive opportunities, make investments to seize opportunities and reconfigure the resource base and the ability to adopt change (Teece, 2007). This dynamic capability will then become a source of significant and sustainable competitive advantage (Wu, 2010).

RBV and dynamic capability have been the basis for important empirical studies related to intangible resources (Newbert, 2008); technological, marketing, or regulatory capabilities and their effect on performance measures (De Carolis, 2003), or the importance of resources and the ability to gain a competitive advantage in public organizations (Symaniec-Micka, 2014).

\subsection{Transformational Leadership}

Transformational leadership was first introduced by James MacGregor in 1978 and, according to Burns (1978), transformational leadership is a process of mutual assistance between leaders and subordinates to advance to a higher level of moral and motivation than ever before. Transformational leadership is also defined as the ability of leaders to motivate employees to exceed the minimum limit of their job descriptions, so as to produce contextual performance that is higher than before (Podsakoff, MacKenzie \& Bommer, 1996). Transformational leaders communicate organizational vision and motivate employees to work towards that vision (Bass, 1985). Transformational leaders also instill pride, communicate privately, facilitate creative thinking, and inspire employees (Lievens et. al., 1997). Transformational leadership will create conditions of mutual care and mutual inspiration between employees which in turn produces high performance (Bass, 1999).

Transformational leadership focuses on what the leader wants to achieve while taking into account the personal characteristics of the leader to their subordinates (DuBrin, 2010). Transformational leadership has four dimensions (Bass \& Avolio, 2003). First, idealized influences, which are charismatic elements of transformational leadership where leaders will be role models who are admired, respected, and imitated by others. Second, inspirational motivation, meaning the leader inspires and motivates by giving meaning and challenge to the work of his subordinates. Third, intellectual stimulation, by gathering new ideas and problem solutions from his subordinates. Finally, individualized consideration, in which leaders' channel personal attention to others based on individual needs for achievement and growth.

A leader with a transformational leadership style is characterized by six behaviors. These are: identifying and articulating a vision, providing an appropriate model, encouraging acceptance of group goals, high performance expectations, providing individual support to staff and intellectual stimulation (Podsakoff, McKenzie, Moorman, \& Fetter, 1990). The understanding of the behavioral characteristics of transformational leaders was extended by Charles, Wearing and Mann (2000) to include seven behaviors, which are developed based on Podsakoff, McKenzie, Moorman, and Fetter (1990). The seven behaviors are: (1) communicates a vision, (2) develops staff, (3) provides support, (4) empowers staff, (5) is innovative, (6) leads by example, and (7) is charismatic.

Past empirical studies have been conducted to examine the effect of transformational leadership on individual performance (Buil et. al., 2018; Dvir, Eden, Avolio, \& Shamir, 2002; Wang, Law, Hackett, Wang,

Global J. Bus. Soc. Sci. Review 7 (4) 224 -238 (2019) 
$\&$ Chen, 2005) and the effect of transformational leadership on organizational performance (Aragon-Correa et. al., 2007; Choudhary et. al., 2013; Peterson, Walumbwa, Byron, \& Myrowitz, 2009; Rowe et. al., 2005). Previous research has also shown that transformational leadership has an indirect effect on organizational performance through culture (Ogbonna \& Harris, 2000), knowledge management (Birasnav, 2014; Gowen et. al., 2009), entrepreneurship (Morales et. al., 2006), human resource management (Zhu et. al., 2005), and competitive strategies (Menguc et. al., 2007). The indirect relationship between transformational leadership and organizational performance can also be seen through organizational capabilities. Previous studies have examined the effect of transformational leadership on organizational performance through organizational capability elements such as through innovation (Arago'n-Correa et. al., 2007; Farr \& Ford, 1990; Morales et. al., 2012; Kanter, 1983; Para-González, 2018) and organizational learning (Aragón-Correa et. al., 2007; Morales et. al., 2012; Para-González, 2018). This study seeks to investigate empirically whether transformational leadership influences organizational performance through organizational capabilities, where organizational capabilities are seen from marketing capabilities, technical capabilities and organizational capabilities as a whole (López-Cabarcos et. al., 2015; López-Cabarcos et. al., 2019; Ali et. al., 2019).

\subsection{Organizational Capabilities}

Organizational capability is a strategy that can bring the organization a competitive advantage so that it has an impact on performance (Henri, 2006). Organizational capability refers to an organization's capacity to maintain combined resources in an organizational process to influence the final outcome (Amit \& Schoemaker, 1993). Barney (1991), Peteraf (1993), and Prahalad and Hamel (1990) argue that an organization can survive in a highly competitive environment due to its ability to create new resources, form a good capability program, and make capabilities more unique so that it cannot be imitated by other organizations.

Teece et. al. (1997) and Jones et. al. (2005) argue that the concept of organizational capability has a foundation in competitive advantage. The recourse-based view (RBV) theory also considers that organizational capability can be used to maintain competitive advantage (Lekatompessy, 2012; Singh, et. al., 2019). Whereas dynamic capability theory posits that to maintain a sustainable competitive advantage, organizations must have capabilities that involve sensing and forming opportunities and threats, seizing opportunities, managing threats and reconstructing organizations (Teece, 2007). This theory also posits that in a non-static environment, companies must change the way they create and capturing value through future vision, business model innovation and future strategies to obtain and maintain sustainable competitive advantage (Eisenhardt et. al., 2010; Teece, 2007).

Most previous studies examine organizational capabilities and tested them partially. Organizational capability is seen as innovation (Miller \& Friesen, 1982), or market orientation (Subramanian \& Gopalakrishna, 2001). Baker and Sinkula (1999) and Arago'n-Correa (2007) conducted a study of organizational capabilities in terms of market orientation and learning orientation. Bhuian et. al., (2005) studied organizational capabilities as entrepreneurship and market orientation. Organizational capability is seen by Deshpande and Farley (2004) as market orientation and innovation. Hurley and Hult (1998) looked at organizational capabilities with innovation, market orientation, and organizational learning. Henri (2006) conducted a study about organizational capabilities and in his research Henri (2006) examined the organizational capabilities of four elements namely: market orientation, innovative, organizational learning, and entrepreneurship. In general, previous research has looked at organizational capabilities through market orientation, innovation, organizational learning, and entrepreneurship.

Meanwhile, Spanos and Lioukas (2001) and López-Cabarcos et. al. (2015) view capability as a concept consisting of organizational capability, marketing capability and technical capability. Some researchers studied organizational capabilities partially, such as marketing capabilities (Hooley et. al., 1999; Kamboj \& Rahman, 2015; Takahashi et. al., 2017) and technological capabilities that have the same view as technical capabilities (Vitorino Filho \& Moori, 2018; Wang et. al., 2006).

Global J. Bus. Soc. Sci. Review 7 (4) $224-238$ (2019) 


\subsection{Organizational Performance}

Organizational performance is a reflection of organizational success in achieving its objectives from various activities undertaken (Ventrakaman \& Ramanujam, 1986). Waterhaouse and Svendsen (1998:59) define performance as measurable actions or activities. Organizational performance is an indicator of the level of success in achieving organizational goals.

There are various indicators that can be used to measure organizational performance. Lee and Miller (1996) measure organizational performance using sales growth, revenue growth, market share growth, asset growth, new product development, employee morale and employee welfare as indicators. Agarwal et. al., (2003) measure organizational performance using two dimensions, namely objective and subjective performance. Objective performance is related to financial performance and marketing performance such as profitability and market share. Whereas subjective performance is based on measurements of customers and employees such as service quality, customer satisfaction and others.

Henri (2006) notes that performance measures began to develop in the early 1990s and culminated in 1996. Lynch and Cross (1991) in Henri (2006) introduced a performance pyramid linking strategy and operations by translating strategic objectives from top-down measures and bottom-up size. In 1992 and 1996, Kaplan and Norton proposed a form of performance measurement called the balance scorecard. Kaplan and Norton assumed that financial perspectives alone did not adequately describe organizational performance. Therefore, the concept of performance measurement of the resulting balance scorecard is not only seen from a financial perspective, but also from a non-financial perspective consisting of a customer perspective, internal process perspective and organizational capacity.

Along with the development of various types of businesses, a type of businesses which main purpose is to create value for society is gaining popularity (Certo \& Miller 2008). This type of business combines profit seeking and social goals (Peredo \& McLean 2006; Neck et. al., 2009). This kind of business has two elements in measuring its success; financial and social performance. Financial performance measures the ability of an organization to generate profits to support its social goals. Social performance can be measured by evaluating the sustainability of resources and production methods, the number of activities carried out to achieve the established social mission, the positive effects of social activities carried out and the long-term impact of social activities carried out on the wider community (Bagnoli \& Megali, 2011). In this study, the performance of village-owned enterprises is measured by looking at their financial performance and social performance since the village-owned business enterprises in carrying out its business has two functions, namely financial functions and social functions. The two functions are interrelated, where the financial function encourages village-owned enterprises to continue to improve their social performance for the community.

\subsection{Transformational Leadership and Organizational Capabilities}

Leadership is a process in which a leader influences subordinates in seeking subordinate voluntary participation to achieve organizational goals (Arshad et. al., 2016). Therefore, a leader can be defined as a person who delegates or influences others to act in carrying out goals (Morales et. al, 2012). Significantly increased business competition with a changing business environment forces organization to keep abreast of these changes in order to survive. For this reason, organizations need leaders who have the ability to understand the complexities of a rapidly changing and dynamic global environments. Different leadership styles will have different impacts within the organization (Buil et. al., 2018).

Transformational leadership style is a leadership style that increases awareness of collective interests among members of the organization and helps them to achieve their collective goals (Morales et. al., 2012). Transformational leadership seeks to create emotional connections with subordinates and inspire them to higher values. Transformational leadership is committed to organizational goal. Therefore, transformational leadership will strive to encourage all employees to commit to the results they achieve (Bass, 2000).

Global J. Bus. Soc. Sci. Review 7 (4) $224-238$ (2019) 
Transformational leaders try to make changes to organizations with the aim of shaping them into something different (Arshad et. al., 2016). This is done to prepare the organization for challenges, such as dealing with new technology or new competitors. These changes can be made by developing capabilities that are in improving core business processes and sustainable learning (Senge, 1990; Zott, 2003).

Capability is the ability of an organization to carry out its tasks or activities in a coordinated manner so as to achieve organizational goals (Eikelenboom, 2005; O'Regan et. al., 2006). The capability must focus on three important elements (a) managing an efficient and effective production department that is open to product and process innovation, (b) developing technical knowledge and expertise by exploring economies of scale, and (c) investing in equipment and technological capabilities (López-Cabarcos et. al., 2015). LópezCabarcos et. al. (2015) divides organizational level capabilities into 3 elements namely: organizational capabilities, marketing capabilities and technical capabilities. Leaders who are able to make changes will be able to recognize and analyze the capabilities possessed by the organization. With these abilities, the resources owned by the organization be utilized properly in accordance with organizational goals. Based on the above discussion, the following hypothesis is proposed:

H1 Transformational leadership has a positive effect on organizational capabilities.

\subsection{Transformational Leadership and Financial Performance}

Transformational leadership describes how leaders can encourage, develop, and implement significant changes in the company, by empowering employees to direct them to change, to achieve greater quality and efficiency of all organizational business processes (Bass, 1999; Lievens et. al., 1997). To achieve positive change, leaders must have certain characteristics and skills, be role models for subordinates (charisma), have a set of moral values that are highly developed, must be competent, reliable, have a vision and be able to motivate others to accept that vision and implement it.

Transformational leadership theory states that leaders exhibit certain behaviors that accelerate the level of employee innovation so as to improve employee performance, organizational innovation, and organizational performance (Colbert, Kristof-Brown, Bradley, \& Barrick, 2008). By implementing transformational leadership, leaders will easily direct their subordinates to achieve organizational goals. With the proper implementation of business processes, the company's financial performance can be improved. Previous research provides evidence that transformational leadership influences financial performance (Avolio et. al., 1988; Barling, Weber \& Kelloway, 1996; Howell \& Avolio, 1993; Koene, Vogelaar \& Soeters, 2002; Strukan, Nikolic \& Sefic, 2017). Thus, the proposed hypothesis is:

H2 Transformational leadership has a positive effect on financial performance.

\subsection{Transformational Leadership and Social Performance}

As mentioned above, village-owned enterprises not only have the aim of generating profit but also have social goals. Organizational social goals can be achieved if all members of the organization understand the social value of the organization and leaders have an important role in transmitting values (Abu Tineh et. al., 2008). Transforming values, attitudes, and motives of employees from a low level to a higher level of passion and maturity will enable the achievement of high performance (Bass, 1985).

Burns (1978) suggests that transformational leadership occurs when leaders and subordinates increase each other's higher values and motivations and produce a transformation effect on leaders and subordinates. Employees under transformational leaders have full confidence in the leader's vision and mission. So that leaders who have transformational leadership will be able to instil the values and social goals to be achieved by the organization and transform it to employees. The process of transforming the values and objectives will result in a transformation in the activities and performance of employees. That way leaders and employees 
together will provide an influence on improving social performance. Transformational leadership can improve organizational performance (Singh et. al., 2015). In addition, transformational leadership contributes significantly to effective organizational policy and performance (Bass, 1998). Transformational leadership is also predicted to improve an organization's social performance. Based on above discussion, the following hypothesis is proposed:

H3 Transformational leadership has a positive effect on social performance.

\subsection{Organizational Capabilities and Financial Performance}

A dynamic business environment forces organization to be able to maintain business sustainability by creating a competitive advantage. An organization's competitive advantage depends on its capabilities to acquire, integrate, and reconfigure resources in responding to a changing business environment (LópezCabarcos et. al., 2015). The main theory of dynamic capability (Eisenhardt \& Martin, 2000; Teece et. al., 1997) supports the idea that performance and competitive advantage results from reconfiguring resources that are appropriate to their environment.

Organizational capability is a strategy that can bring an organization a competitive advantage (Henri, 2006). Organizational capability is important to assist organizations in relation to management and organizational processes, leader competencies, employee knowledge and skills, efficient organizational structure, organizational culture, existing coordination mechanisms, strategic planning procedures, and the ability to attract employee creativity (Galbreath, 2005; Teece et. al., 1997). Organizations with capabilities will be able to manage operational activities more effectively and efficiently and make management and employees more productive. This will improve financial performance, as seen by an increase in organizational income. The resulting profit illustrates the increase in financial performance achieved by the organization.

Based on the RBV theory, dynamic capability theory and empirical findings, capabilities have been considered as antecedents to performance (Wernerfelt, 1984). Several studies have shown a positive relationship between capability and performance (Richey, Tokman, \& Dalela, 2010; Lekatompessy, 2012). López-Cabarcos et. al., (2015) have also proven that capability and profitability have a positive relationship. Based on the above discussion, the following hypothesis is proposed:

H4 Organizational capabilities have a positive effect on financial performance.

\subsection{Organizational Capabilities and Social Performance}

The creation of social value is the main goal of village-owned enterprises, while the creation of economic value is needed in order to encourage the organization to improve its social performance (Mair \& Martí, 2006). Social value refers to the supply of goods and services needed for an organization's social purposes such as community service, community development, community economic improvement, or dealing with various other social problems (Austin, Stevenson \& Wei Skillern, 2006; Sud, Van Sandt, \& Baugous, 2009).

To be able to achieve the organization's social goals, the organization must have the ability to manage its resources (Bagnoli \& Megali, 2011). Several studies have focused on resource theory and capabilities in assessing the achievement of organizational goals. This approach stresses the importance of analysing the organization's resources and capabilities, their use, characteristics, or new capabilities that result in organizations from existing and complementary interactions (Barney, 2002; Grant, 1996). With the abilities and capabilities of the organization in managing and analysing its resources, this will support the organization in achieving its goals. Village-owned enterprises that prioritize social goals will be able to achieve higher social performance so that the benefits will be felt by the community. The study of the effect 
of organizational capability on social performance is still limited. This study aims to identify the focus of capability relationships on social performance. Therefore, the following hypothesis is proposed:

H5 Organizational capabilities have a positive effect on social performance.

\subsection{Transformational Leadership, Organizational Capabilities and Financial Performance}

Several studies have been conducted to determine the direct effect of transformational leadership on financial performance, profitability and other financial measures (Purvee \& Enkhtuvshin, 2015; Wongyanon et. al., 2015). Several previous studies have also examined the relationship of organizational capabilities to financial performance. In this study, organizational capability is positioned as a mediating variable that mediates the relationship between transformational leadership and financial performance. This is based on the argument that transformational leadership is the ability of leaders to align employee goals and organizational goals. This will cause the employee to fully trust the leader, resulting in higher motivation in the employee. That way, employees make greater contributions to produce creativity that is beneficial to the organization. The process of production and management of the organization will also be more effective and efficient, all of which are capabilities possessed by the organization. Through this organizational capability that can be optimized, the organization will be able to experience an increase in revenue which will impact its financial performance. Based on above discussion, the following hypothesis is proposed:

H6 Organizational capabilities mediate the relationship between transformational leadership and financial performance.

\subsection{Transformational Leadership, Organizational Capabilities and Social Performance}

Transformational leadership can affect social performance if the leader is able to empower the capabilities of the organization. Transformational leaders are able to maximize the utilization of capabilities owned by the organization. Leaders will also be able to explain the company's social goals to employees and direct them towards these goals (Bass, 1985; Bass, 1999; Lievens et. al., 1997). That way, employees will align their goals towards the organization's social goals, and ultimately have an impact on improving the organization's social performance. Therefore, the proposed hypothesis is:

H7 Organizational capabilities mediate the relationship between transformational leadership and social performance.

\section{Research Methodology}

This is a quantitative study which uses a questionnaire to obtain data. The data in this study was analyzed using Structural Equation Modelling-Partial Least Square (SEM-PLS) using WarpPLS 5.0. The population in this study is 121 Village-Owned Enterprise in Siak Regency, Riau Province, Indonesia. All of the member of the population were taken as a sample. The respondents in this study were the directors of Village-Owned Enterprises. The questionnaires were handed over directly to the directors. The respondents were asked to rate their perception of the statements given using a 1-10 scale from strongly disagree (1) to strongly agree (10).

This study investigates three constructs namely: transformational leadership, organizational capability and organizational performance. Transformational Leadership was measured using 7 items adopted from Carless, Wearing and Mann (2000). Organizational capability in this study is defined as the ability of the organization to carry out its tasks or activities in a coordinated manner so as to achieve organizational goals. This is measured using instruments developed by López-Cabarcos et. al., (2015) and Spanos and Lioukas (2001).

Global J. Bus. Soc. Sci. Review 7 (4) 224 -238 (2019) 
There are 14 items to measure capabilities; 7 items to measure organizational capability, 4 items to measure marketing capability and 3 items to measure technical capability. Organizational performance consists of financial performance and social performance. Organizational performance is measured by 5 items consisting of 3 items of financial performance and 2 items of social performance. The instrument used was adopted from Widener (2007) and Bagnoli and Megali (2011).

\section{Results}

From the 121 questionnaires distributed, 94 questionnaires were returned. 5 questionnaires were dropped due to incomplete responses. Therefore, only 87 responses (73.55\% response rate) can be further analysed.

\subsection{Assessment of the Model}

An evaluation of the model was conducted by testing the validity and reliability of the model. Validity is evaluated through a confirmatory factor analysis by examining convergent validity and discriminant validity (Latan \& Ghozali, 2012). Convergent validity is assessed using the loading indicator. This research model has a loading between 0.614-0.907 and greater than 0.50. AVEs are in the range of 0.530-0.744 and greater than 0.50. This indicates that the indicators used in this study can explain each variable (Chin, 1998; Hair et. al., 2014). Discriminant validity is performed by comparing R2 of average variance extracted (AVE) of each construct with correlation or construct with other constructs in the model. Correlations among latent variables. With R2 of AVEs shows that the R2 of AVE of each construct is greater than the correlation between constructs and other constructs in the model, so this research model has good discriminant validity (Fornell \& Larcker, 1981 in Ghozali 2014: 40).

The reliability of data can be assessed through Cronbach's alpha and Composite reliability. In this study Cronbach's alpha has a value between 0.657-0.931. Composite reliability has a value between 0.854-0.927 and is greater than 0.70 . This shows that all instruments used are error free and consistent in every construct with high reliability.

\subsection{Assessment of Inner (Structural) Model}

Figure 1 below shows the R2 on the organizational capability is 0.506 , while R2of financial performance and social performance are 0.472 and 0.547 respectively.

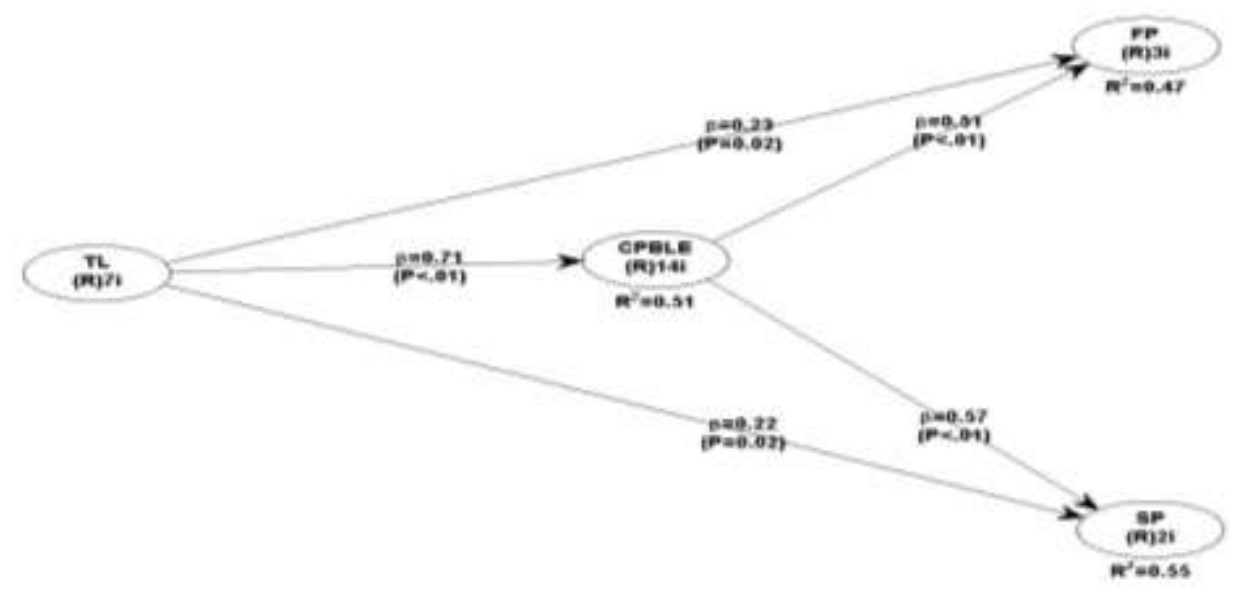

Figure 1. Full Structural Equation Model 


\subsection{Direct Effect}

Based on Figure 1 above, transformational leadership has a positive effect on organizational capability ( $\beta$ $=0.711, \mathrm{PV}<0.001)$. Transformational leadership has a positive effect on organizational performance, both on financial performance $(\beta=0.229, \mathrm{PV}=0.019)$ and social performance $(\beta=0.221, \mathrm{PV}=0.024)$. Organizational capability has a positive influence on organizational performance, which has a positive effect on financial performance $(\beta=0.506, \mathrm{PV}<0.001)$ and a positive effect on social performance $(\beta=0.566, \mathrm{PV}$ $<0.001)$. Therefore $\mathrm{H} 1, \mathrm{H} 2, \mathrm{H} 3, \mathrm{H} 4$ and $\mathrm{H} 5$ are accepted.

\subsection{Indirect Effect}

Based on Table 2 below, it was found that organizational capabilities are able to act as a mediator that relates transformational leadership to financial performance $(\mathrm{VAF}=37.94 \%)$ and a mediator for the relationship between transformational leadership and social performance $(\mathrm{VAF}=39.18 \%)$. In this study organizational capabilities act as a partial mediator. Therefore $\mathrm{H} 6$ and $\mathrm{H} 7$ are accepted.

Table 2. Result of the PLS for Indirect Effect

\begin{tabular}{lllll}
\hline Path & $\mathbf{a x b}(\mathbf{1})$ & $\mathbf{a x b + c ( 2 )}$ & $\mathbf{V A F}=\mathbf{( 1 ) / ( 2 ) \times 1 0 0 \%}$ & Decision \\
\hline $\mathbf{T L} \rightarrow \mathbf{O C} \rightarrow \mathbf{F P}$ & $0.711 \times 0.506=0.360$ & $0.360+0.588=0.948$ & $20 \%<37.94 \%<80 \%$ & $\begin{array}{l}\text { Partial } \\
\text { mediation }\end{array}$ \\
$\mathbf{T L} \rightarrow \mathbf{O C} \rightarrow \mathbf{S P}$ & $0.711 \times 0.566=0.402$ & $0.402+0.624=1.026$ & $20 \%<39.18 \%<80 \%$ & $\begin{array}{l}\text { Partial } \\
\text { mediation }\end{array}$ \\
\hline
\end{tabular}

\section{Notes:}

$\mathrm{a}=$ path coefficient value of predictor variable to mediator, with the significance of $\mathrm{p}<0.05$

$b=$ path coefficient value of mediator variable to criterion, with the significance of $p<0.05$

$\mathrm{c}=$ path coefficient value of the predictor variable on criterion before the mediator variable included in the model, with a significance of $\mathrm{p}<0.05(\beta=0.588 ; \beta=0.624 ; \mathrm{p}<0.01)$

\section{Discussion}

This study has 7 hypotheses that were tested using data obtained from the directors of Village-Owned Enterprises in Siak Regency, Riau Province, Indonesia. The results of this study indicate that the impact of transformational leadership on financial performance and social performance can be enhanced through the utilization of capabilities (organizational, marketing, and technical capabilities) owned by the organization. This research has proven that transformational leadership has impact to organizational capability. This research is in line with Hamidizadeh, Oboudi and Ramezani (2017).

Organizational capabilities which include marketing and technical capabilities are very important capabilities for the organization to have in order to survive in a dynamic business environment. These capabilities will be able to be owned and developed if the organization's leaders have transformational leadership, so they can motivate employees to explore their capabilities (Bass, 1985). As a consequence, in order to improve organizational performance, Village-Owned Enterprises or other businesses organizations need to pay attention to transformational leadership in determining organizational leaders. This result is consistent with López-Cabarcos, et. al., (2015). Organizations need to consider the characteristics of transformational leaders in determining leaders. Thus, organizations that have leaders who are able to understand the capabilities of the organization and then empower it will be able to compete in a dynamic business environment. 


\section{Conclusion}

This research is aims to analyse the extent to which transformational leadership enhances village-owned enterprise performance through organizational capabilities. All hypotheses proposed are accepted. Although this research has succeeded in achieving its objectives, generalization of the results must be carried out with caution. This research is only conducted in village-owned enterprises in one district in Indonesia. Therefore, this will limit the generalization of this study. This study only considers transformational leadership and organizational capabilities as variables that will improve the performance of village-owned enterprises. Future research can expand populations and add other variables to broaden the understanding of how the performance of village-owned enterprises can be improved.

\section{References}

Abu-Tineh, A. M., Khasawneh, S. A., \& Al-Omari, A. A. (2008). Kouzes and Posner's transformational leadership model in practice: The case of Jordanian schools. Leadership \& Organization Development Journal, 29(8), 648660.https://doi.org/10.1108/01437730810916613

Agarwal, S., Krishna Erramilli, M., \& Dev, C. S. (2003). Market orientation and performance in service firms: role of innovation. Journal of services marketing, 17(1), 68-82. https://doi.org/10.1108/08876040310461282

Ali, Z., Zwetsloot, I. M., \& Nada, N. (2019). An empirical study to explore the interplay of Managerial and Operational capabilities to infuse organizational innovation in SMEs. Procedia Computer Science, 158, 260-269. https://doi.org/10.1016/j.procs.2019.09.050

Amit, R., \& Schoemaker, P. J. (1993). Strategic assets and organizational rent. Strategic management journal, 14(1), 33 46. https://doi.org/10.1002/smj.4250140105

Aragón-Correa, J. A., García-Morales, V. J., \& Cordón-Pozo, E. (2007). Leadership and organizational learning's role on innovation and performance: Lessons from Spain. Industrial marketing management, 36(3), 349-359. https://doi.org/10.1016/j.indmarman.2005.09.006

Arshada, A. S., Raslib, A. A. A., \& Mohd, Z. (2016). Transformational Leadership and Business Performance: An Insight from Technology-based SMEs in Malaysia.http://dx.doi.org/10.15405/epsbs.2016.11.02.5

Austin, J., Stevenson, H., \& Wei-Skillern, J. (2006). Social and commercial entrepreneurship: same, different, or both? Entrepreneurship theory and practice, 30(1), 1-22. https://doi.org/10.1111\%2Fj.1540-6520.2006.00107.x

Avolio, B. J., Waldman, D. A., \& Einstein, W. O. (1988). Transformational leadership in a management game simulation: Impacting the bottom line. Group \& Organization Studies, 13(1), 59-80. https://doi.org/10.1177/105960118801300109

Bagnoli, L., \& Megali, C. (2011). Measuring performance in social enterprises. Nonprofit and Voluntary Sector Quarterly, 40(1), 149-165.https://doi.org/10.1177\%2F0899764009351111

Baker, W. E., \& Sinkula, J. M. (1999). Learning orientation, market orientation, and innovation: Integrating and extending models of organizational performance. Journal of market-focused management, 4(4), 295-308. https://ideaexchange.uakron.edu/marketing_ideas/272

Barling, J., Weber, T., \& Kelloway, E. K. (1996). Effects of transformational leadership training on attitudinal and financial outcomes: A field experiment. Journal of applied psychology, 81(6), 827. https://doi.org/10.1037/00219010.81.6.827

Barney, J. B.(2002). Gaining and sustaining competitive advantage. Upper Saddle River, NJ: Prentice Hall. https://scinapse.io/papers/1507501762

Barney, J. (1991). Special theory forum the resource-based model of the firm: origins, implications, and prospects. Journal of management, 17(1), 97-98. Journal of management, 17(1), 97-98. https://doi.org/10.1177/014920639101700107

Bass, B. M., \& Bass Bernard, M. (1985). Leadership and performance beyond expectations.

Bass, B. M. (1990). From transactional to transformational leadership: Learning to share the vision. Organizational dynamics, 18(3), 19-31. https://doi.org/10.1016/0090-2616(90)90061-S

Bass, B. M. (2000). The future of leadership in learning organizations. Journal of leadership studies, 7(3), 18-40. https://doi.org/10.1177/107179190000700302 
Bassett-Jones, N. (2005). The paradox of diversity management, creativity and innovation. Creativity and innovation management, 14(2), 169-175. https://doi.org/10.1111/j.1467-8691.00337.x

Bhuian, S. N., Menguc, B., \& Bell, S. J. (2005). Just entrepreneurial enough: the moderating effect of entrepreneurship on the relationship between market orientation and performance. Journal of business research, 58(1), 9-17. https://doi.org/10.1016/S0148-2963(03)00074-2

Birasnav, M. (2014). Knowledge management and organizational performance in the service industry: The role of transformational leadership beyond the effects of transactional leadership. Journal of business research, 67(8), 16221629. https://doi.org/10.1016/j.jbusres.2013.09.006

Buil, I., Martínez, E., \& Matute, J. (2019). Transformational leadership and employee performance: The role of identification, engagement and proactive personality. International Journal of Hospitality Management, 77, 64-75. https://doi.org/10.1016/j.ijhm.2018.06.014

Burns, J.M. (1978) 'Leadership', in Heymann, K.(1992) (Ed.): Quality Management: A Ten-point Model, Cornell Hotel and Restaurant Administration, 33 (5), pp.51-60, Harper Row,NY.

Carless, S. A. (1995). Transformational leadership and Australian bank managers. University of Melbourne.

Certo, S. T., \& Miller, T. (2008). Social entrepreneurship: Key issues and concepts. Business horizons, 51(4), $267-271$. http://www.sciencedirect.com/science/article/pii/S0007-6813(08)00039-6

Chen, J. X., Sharma, P., Zhan, W., \& Liu, L. (2019). Demystifying the impact of CEO transformational leadership on firm performance: Interactive roles of exploratory innovation and environmental uncertainty. Journal of Business Research, 96, 85-96. https://doi.org/10.1016/j.jbusres.2018.10.061

Chin, W. W. (1998). The partial least squares approach to structural equation modeling. Modern methods for business research, 295(2),

295-

336.https://www.researchgate.net/publication/311766005_The_Partial_Least_Squares_Approach_to_Structural_Equati on_Modeling

Choudhary, A. I., Akhtar, S. A., \& Zaheer, A. (2013). Impact of transformational and servant leadership on organizational performance: A comparative analysis. Journal of business ethics, 116(2), 433-440. https://link.springer.com/article/10.1007/s10551-012-1470-8

De Carolis, D. M. (2003). Competencies and imitability in the pharmaceutical industry: An analysis of their relationship with firm performance. Journal of management, 29(1), 27-50. https://doi.org/10.1016/S0149-2063(02)00220-9

Deshpandé, R., \& Farley, J. U. (2004). Organizational culture, market orientation, innovativeness, and firm performance: an international research odyssey. International Journal of Research in Marketing, 21(1), 3-22. https://doi.org/10.1016/j.ijresmar.2003.04.002

DuBRIN, A. J. (1995). Research findings, practice and skills.

Dvir, T., Eden, D., Avolio, B. J., \& Shamir, B. (2002). Impact of transformational leadership on follower development and performance: A field experiment. Academy of management journal, 45(4), 735744.https://www.jstor.org/stable/3069307?seq=1

Eikelenboom, B. (2005). Organizational capabilities and bottom-line performance: The relationship between organizational architecture and strategic performance of business units in Dutch headquartered multinationals. Eburon Uitgeverij BV.

Eisenhardt, K. M., Furr, N. R., \& Bingham, C. B. (2010). CROSSROADS-Microfoundations of performance: Balancing efficiency and flexibility in dynamic environments. Organization science, 21(6), 1263-1273. https://www.jstor.org/stable/40926741?seq=1

Eisenhardt, K. M., \& Martin, J. A. (2000). Dynamic capabilities: what are they?. Strategic management journal, 21(1011), 1105-1121. https://doi.org/10.1002/1097-0266(200010/11)21:10/11\%3C1105::AID-SMJ133\%3E3.0.CO;2-E

Elenkov, D. S. (2002). Effects of leadership on organizational performance in Russian companies. Journal of Business Research, 55(6), 467-480. https://doi.org/10.1016/S0148-2963(00)00174-0

Farr, J. L., \& Ford, C. M. (1990). Individual innovation. https://psycnet.apa.org/record/1991-97989-003

Galbreath, J. (2005). The intangible economy and firm superior performance: Evidence from Australia. Journal of Management \& Organization, 11(1), 28-40. https://doi.org/10.1017/S1833367200004399

Garcia-Morales, V. J., Llorens-Montes, F. J., \& Verdú-Jover, A. J. (2006). Antecedents and consequences of organizational innovation and organizational learning in entrepreneurship. Industrial Management \& Data Systems, 106(1), 21-42. https://doi.org/10.1108/02635570610642940 
García-Morales, V. J., Jiménez-Barrionuevo, M. M., \& Gutiérrez-Gutiérrez, L. (2012). Transformational leadership influence on organizational performance through organizational learning and innovation. Journal of business research, 65(7), 1040-1050. https://doi.org/10.1016/j.jbusres.2011.03.005

Ghozali, I. (2012). Structural Equation Modeling: Alternative Methods with Partial Least Square. Publisher Agency Diponegoro University.

Ghozali, Imam \& Latan.(2014). Structural Equation Modeling: Alternative Methods with Partial Least Square. Publisher Agency Diponegoro University.

Giambatista, R. C., Rowe, W. G., \& Riaz, S. (2005). Nothing succeeds like succession: A critical review of leader succession literature since 1994. The Leadership Quarterly, 16(6), 963-991. https://doi.org/10.1016/j.leaqua.2005.09.005

Gowen III, C. R., Henagan, S. C., \& McFadden, K. L. (2009). Knowledge management as a mediator for the efficacy of transformational leadership and quality management initiatives in US health care. Health care management review, 34(2), 129-140. https://insights.ovid.com/crossref?an=00004010-200904000-00003

Grant, R. M. (1996). Toward a knowledge-based theory of the firm. Strategic management journal, 17(S2), $109-122$. https://doi.org/10.1002/smj.4250171110

Hair, J. F., M. Sarstedt, L. Hopkins, V. G.Kuppelwieser.(2014).Partial Least Squares Structural Equation Modeling (PLS-SEM): An Emerging Tool in Business Research. European business review. 26(2),106-121. https://doi.org/10.1108/EBR-10-2013-0128

Hamidizadeh, M. R., Oboudi, M., \& Ramezani, S. The Impact of Transformational Leadership on Organizational Performance through Organizational Learning and Organizational Innovation. Journal of Administrative Management, Education and Training, 13, 59-72. http://www.jamet-my.org/archive/2017/I00S8-02/59-72.pdf

Henri, J. F. (2006). Management control systems and strategy: A resource-based perspective. Accounting, organizations and society, 31(6), 529-558. https://doi.org/10.1016/j.aos.2005.07.001

Hooley, G., Fahy, J., Cox, T., Beracs, J., Fonfara, K., \& Snoj, B. (1999). Marketing capabilities and firm performance: a hierarchical model. Journal of market-focused management, 4(3), 259-278. https://link.springer.com/article/10.1023/A:1009879120167

Howell, J. M., \& Avolio, B. J. (1993). Transformational leadership, transactional leadership, locus of control, and support for innovation: Key predictors of consolidated-business-unit performance. Journal of applied psychology, 78(6), 891. https://doi.org/10.1037/0021-9010.78.6.891

Hurley, R. F., \& Hult, G. T. M. (1998). Innovation, market orientation, and organizational learning: an integration and empirical examination. Journal of marketing, 62(3), 42-54. https://www.jstor.org/stable/1251742?seq=1

Kamboj, S., \& Rahman, Z. (2015). Marketing capabilities and firm performance: literature review and future research agenda. International Journal of Productivity and Performance Management, 64(8), 10411067.https://doi.org/10.1108/IJPPM-08-2014-0117

Kanter, R. M. (1983). The change masters New York-Simon and Schuster. KanterThe Change Masters 1983.

Koene, B. A., Vogelaar, A. L., \& Soeters, J. L. (2002). Leadership effects on organizational climate and financial performance: Local leadership effect in chain organizations. The Leadership Quarterly, 13(3), $193-215$. https://doi.org/10.1016/S1048-9843(02)00103-0

Kouzes, J.,Posner, B. (1999). "Encouraging the Heart." San Francisco, CA: Jossey-Bass Inc., Publishers. https://keithdwalker.ca/wp-content/summaries/d-

f/Encouraging\%20the\%20Heart.Kouze $\% 20 \% 20 \% 26 \% 20$ Posner.EBS.pdf

Krasnikov, A., \& Jayachandran, S. (2008). The relative impact of marketing, research-and-development, and operations capabilities on firm performance. Journal of marketing, 72(4), 1-11. https://doi.org/10.1509/jmkg.72.4.001

Lee, J., \& Miller, D. (1996). Strategy, environment and performance in two technological contexts: contingency theory in Korea. Organization Studies, 17(5), 729-750.https://doi.org/10.1177/017084069601700502

Lekatompessy, J. E. (2012). The role of management control systems in enhancing firm performance: Contingency analysis and resource-based view. (Doctoral dissertation, University of Diponegoro, Indonesia). http://eprints.undip.ac.id/40889/1/bab_1-3.pdf

Liao, H., \& Chuang, A. (2007). Transforming service employees and climate: A multilevel, multisource examination of transformational leadership in building long-term service relationships. Journal of applied psychology, 92(4), 1006. https://doi.org/10.1037/0021-9010.92.4.1006 
Lievens Pascal Van Geit Pol Coetsier, F. (1997). Identification of transformational leadership qualities: An examination of potential biases. European Journal of Work and Organizational Psychology, 6(4), 415-430. https://doi.org/10.1080/135943297399015

López-Cabarcos, M. Á., Göttling-Oliveira-Monteiro, S., \& Vázquez-Rodríguez, P. (2015). Organizational capabilities and profitability: The mediating role of business strategy. Sage Open, 5(4), 2158244015616852. ttps://doi.org/10.1177/2158244015616852

López-Cabarcos, M. Á., Srinivasan, S., Göttling-Oliveira-Monteiro, S., \& Vázquez-Rodríguez, P. (2019). Tacit knowledge and firm performance relationship. The role of product innovation and the firm level capabilities. Journal of Business Economics and Management, 20(2), 330-350.https://doi.org/10.3846/jbem.2019.9590

Mair, J., \& Marti, I. (2006). Social entrepreneurship research: A source of explanation, prediction, and delight. Journal of world business, 41(1), 36-44. https://doi.org/10.1016/j.jwb.2005.09.002

Menguc, B., Auh, S., \& Shih, E. (2007). Transformational leadership and market orientation: Implications for the implementation of competitive strategies and business unit performance. Journal of business research, 60(4), 314-321. https://doi.org/10.1016/j.jbusres.2006.12.008

Miller, D., \& Friesen, P. H. (1982). Innovation in conservative and entrepreneurial firms: Two models of strategic momentum. Strategic management journal, 3(1), 1-25. https://www.jstor.org/stable/2485899

Neck, H., Brush, C., \& Allen, E. (2009). The landscape of social entrepreneurship. Business horizons, 52(1), 13-19. http://www.sciencedirect.com/science/article/pii/S0007-6813(08)00132-8

Newbert, S. L. (2008). Value, rareness, competitive advantage, and performance: a conceptual-level empirical investigation of the resource-based view of the firm. Strategic management journal, 29(7), 745768.https://doi.org/10.1002/smj.686

Ogbonna, E., \& Harris, L. C. (2000). Leadership style, organizational culture and performance: empirical evidence from UK companies. International Journal of Human Resource Management, 11(4), $766-788$. https://doi.org/10.1080/09585190050075114

O'Regan, N., Ghobadian, A., \& Gallear, D. (2006). In search of the drivers of high growth in manufacturing SMEs. Technovation, 26(1), 30-41. https://doi.org/10.1016/j.technovation.2005.05.004

Para-González, L., Jiménez-Jiménez, D., \& Martínez-Lorente, A. R. (2018). Exploring the mediating effects between transformational leadership and organizational performance. Employee Relations, 40(2), 412-432. https://doi.org/10.1108/ER-10-2016-0190

Peredo, A. M., \& McLean, M. (2006). Social entrepreneurship: A critical review of the concept. Journal of world business, 41(1), 56-65. https://ssrn.com/abstract=1197663

Peteraf, M. A. (1993). The cornerstones of competitive advantage: a resource-based view. Strategic management journal, 14(3), 179-191.https://www.jstor.org/stable/2486921

Peterson, S. J., Walumbwa, F. O., Byron, K., \& Myrowitz, J. (2009). CEO positive psychological traits, transformational leadership, and firm performance in high-technology start-up and established firms. Journal of management, 35(2), 348-368. https://doi.org/10.1177/0149206307312512

Podsakoff, P. M., MacKenzie, S. B., \& Bommer, W. H. (1996). Transformational leader behaviors and substitutes for leadership as determinants of employee satisfaction, commitment, trust, and organizational citizenship behaviors. Journal of management, 22(2), 259-298. https://doi.org/10.1016/S0149-2063(96)90049-5

Prahalad, C. K., \& Hamel, G. (1990). The Core Competence of the coreporation. Harvard BusinessRevien, 5 , 6. https://doi.org/10.1007/3-540-30763-X_14

Purvee, A., \& Enkhtuvshin, D. (2015). Leadership behaviors, trustworthiness, and managers' ambidexterity. International Journal of Innovation, Management and Technology, 6(2), 109. http://www.ijimt.org/vol6/584CM1004.pdf.

Richey, R. G., Tokman, M., \& Dalela, V. (2010). Examining collaborative supply chain service technologies: a study of intensity, relationships, and resources. Journal of the Academy of Marketing Science, 38(1), 71-89. https://link.springer.com/article/10.1007/s11747-009-0139-z

Senge, P. (1990). The leaders' new work: Building learning organizations. Sloan Management Review, 32(1): 7-23. https://sloanreview.mit.edu/article/the-leaders-new-work-building-learning-organizations/

Singh, D., Negin, J., Otim, M., Orach, C. G., \& Cumming, R. (2015). The effect of payment and incentives on motivation and focus of community health workers: five case studies from low-and middle-income countries. Human resources for health, 13(1), 58. https://human-resources-health.biomedcentral.com/articles/10.1186/s12960-015-0051-1 
Song, M., Di Benedetto, C. A., \& Nason, R. W. (2007). Capabilities and financial performance: the moderating effect of strategic type. Journal of the Academy of Marketing Science, 35(1), 18-34. https://link.springer.com/article/10.1007/s11747-006-0005-1

Spanos, Y. E., \& Lioukas, S. (2001). An examination into the causal logic of rent generation: contrasting Porter's competitive strategy framework and the resource-based perspective. Strategic management journal, 22(10), 907-934. https://www.jstor.org/stable/3094376

Strukan, E., Nikolić, M., \& Sefić, S. (2017). Impact of transformational leadership on business performance. Tehnicki Vjesnik, 24(2), 435-444. https://hrcak.srce.hr/file/274445

Subramanian, R., \& Gopalakrishna, P. (2001). The market orientation-performance relationship in the context of a developing economy: An empirical analysis. Journal of Business Research, 53(1), 1-13. https://doi.org/10.1016/S01482963(99)00109-5

Sud, M., VanSandt, C. V., \& Baugous, A. M. (2009). Social entrepreneurship: The role of institutions. Journal of business ethics, 85(1), 201-216. https://doi.org/10.1007/s10551-008-9939-1

Szymaniec-Mlicka, K. (2014). Resource-based view in strategic management of public organizations-a review of the literature. Management, 18(2), 19-30. https://doi.org/10.2478/manment-2014-0039

Teece, D. J., Pisano, G., \& Shuen, A. (1997). Dynamic capabilities and strategic management. Strategic management journal, 18(7), 509-533.https://www.jstor.org/stable/3088148

Teece, D. J. (2007). Explicating dynamic capabilities: the nature and microfoundations of (sustainable) enterprise performance. Strategic management journal, 28(13), 1319-1350. https://doi.org/10.1002/smj.640

Venkatraman, N., \& Ramanujam, V. (1986). Measurement of business performance in strategy research: A comparison of approaches. Academy of management review, 11(4), 801-814. DOI: 10.2307/258398. https://www.jstor.org/stable/258398

Vitorino Filho, V. and Moori, R. (2018), "The role of technological capabilities in the competitive advantage of companies in the Campinas, SP Tech Hub", Innovation \& Management Review, Vol. 15 No. 3, pp. $247-268$. https://doi.org/10.1108/INMR-06-2018-0035

Wang, H., Law, K. S., Hackett, R. D., Wang, D., \& Chen, Z. X. (2005). Leader-member exchange as a mediator of the relationship between transformational leadership and followers' performance and organizational citizenship behavior. Academy of management Journal, 48(3), 420-432. https://doi.org/10.5465/amj.2005.17407908

Wang, Y., Lo, H. P., Zhang, Q., \& Xue, Y. (2006). How technological capability influences business performance: An integrated framework based on the contingency approach. Journal of Technology Management in China, 1(1), 27-52. https://doi.org/10.1108/17468770610642740

Waterhouse, J., \& Svendsen, A. (1998). Strategic Performance Monitoring and Management: Using Non-Financial Measures to Improve Corporate Governance", The Canadian Institute of Chartered Accountants, Toronto, ON.

Wernerfelt, B. (1984). A resource-based view of the firm. Strategic management journal, 5(2), 171-180. https://doi.org/10.1002/smj.4250050207

Widener, S. K. (2007). An empirical analysis of the levers of control framework. Accounting, organizations and society, 32(7-8), 757-788. https://doi.org/10.1016/j.aos.2007.01.001

Widiyanto,Danar.(2019).Kredit Macet di BUMDes Ternyata Masih Tergolong Tinggi.available from https://krjogja.com/web/news/read/109295/Kredit_Macet_di_BUMDes_Ternyata_Masih_Tergolong_Tinggi[Accessed 13 September 2019].

Wongyanon, S., Wijaya, A. F., \& Soeaidy, M. S. (2015). Analysis of the influence of leadership styles of chief executives to organizational performance of local organization in Thailand (a case study of transformational, transactional and laissez-faire styles of leadership in pattaya city, laemchabang city municipality and chonburi provincial organization). International Journal of Applied Sociology, 5(2), 76-83. http://article.sapub.org/10.5923.j.ijas.20150502.02.html

Wu, L. Y. (2010). Applicability of the resource-based and dynamic-capability views under environmental volatility. Journal of Business Research, 63(1), 27-31. https://doi.org/10.1016/j.jbusres.2009.01.007

Zott, C. (2003). Dynamic capabilities and the emergence of intraindustry differential firm performance: insights from a simulation study. Strategic management journal, 24(2), 97-125. https://doi.org/10.1002/smj.288

Zhu, W., Chew, I. K., \& Spangler, W. D. (2005). CEO transformational leadership and organizational outcomes: The mediating role of human-capital-enhancing human resource management. The leadership quarterly, 16(1), 39-52. https://doi.org/10.1016/j.leaqua.2004.06.001 